\section{Attraction factors of shopping centers}

\section{Effects of design and eco-natural environment on intention to visit}

Attraction factors of shopping centers

Leonardo Ortegón-Cortázar

Faculty of Economics, Universidad de Valencia, Valencia, España and

Department of Marketing, Communications, and Arts,

Institución Universitaria Politecnico Grancolombiano, Bogota, Colombia, and

Marcelo Royo-Vela

Faculty of Economics, Universidad de Valencia, Valencia, España
Received 18 May 2016 Revised 12 September 2016 22 December 2016 Accepted 8 February 2017

\begin{abstract}
Purpose - People visit malls not only to buy a product they need but also to enjoy the atmosphere or environment of the shopping center. Based on design and eco-natural environment, the purpose of this paper is to analyze the attraction factors of shopping centers.

Design/methodology/approach - The sample comprised 449 consumers from 25 different shopping centers in Bogota. The structural equation model (AMOS) enables the authors to discuss the influence of the design of green and natural spaces in the commercial management of shopping centers, given its positive and significant effect on the intention to visit.

Findings - Shopping centers are, by definition, spaces with a high level of design of the commercial environment. In this case, as evidenced in the results of this research, the design of ecological spaces and environments has the potential of becoming a field of interest for the commercial management of shopping centers, given its potential effect on visiting and shopping intentions.

Originality/value - The main originality of this study was to empirically include and demonstrate the influence of design and natural eco-environment on the intention to visit, along with other elements considered in previous investigations. Therefore, identification of specific empirical findings related to the way attraction factors work allows marketing directors and managers to improve their management decisions concerning design and implementation of marketing strategies, tactical decision guidance, decision-making assessment or control, and the proposal of alternative positioning attributes, such as the design, management, and arrangement of eco-natural environments that allow to increase the number of visits and purchases within these establishments.
\end{abstract}

Keywords Structural equation modelling, Attraction factors, Shopping centre,

Design and eco-natural environment, Intention to visit

Paper type Research paper

\section{Introduction}

Shopping centers have significantly advanced in the application of joint management methods (Howard, 1992, 1997; De Juan and Rivera, 1999). However, several authors such as McGoldrick and Thompson (1992), Finn and Louviere (1996), Dennis et al. (2002), and Chebat et al. (2010) considered that in addition to the integrated management, shopping centers should improve the offer conditions, their attractiveness, and their image by

JEL Classification - L81, M31, Q56

(C) Leonardo Ortegón-Cortázar and Marcelo Royo-Vela. Published in the European Journal of Management and Business Economics. Published by Emerald Publishing Limited. This article is published under the Creative Commons Attribution (CC BY 4.0) licence. Anyone may reproduce, distribute, translate and create derivative works of this article (for both commercial and non-commercial purposes), subject to full attribution to the original publication and authors. The full terms of this licence may be seen at http://creativecommons.org/licences/by/4.0/legalcode 
EJMBE

26,2

200

considering other alternative or complementary factors. Different studies have supported the interest of investigating the establishments that have introduced and developed a type of management facilitating the exploitation of the trade market. Some studies have focused on increasing their attractiveness and the fidelity of their client through their image (Ortegon and Royo, 2015; Chebat et al., 2010; Vigaray and Camino, 1999), becoming a space for meetings, entertainment, leisure, relaxation, and interchange (Porral and Dopico, 2013). Other studies have focused on providing memorable experiences of diverse sensorial, emotional, and behavioral (Ortegon and Gomez, 2017; Kim et al., 2015; Kim, 2001). Such issues described in further detail by Srinivasan and Srivastava (2010) and Tandon et al. (2016) are not developed here for the purpose of this study.

The literature on the attraction factors of shopping centers has focused on the possibility of model creation to determine the demand for attraction and the intention to visit (El-Adly and Eid, 2016; McGoldrick and Thompson, 1992; Finn and Louviere, 1996; Chebat et al., 2010). These approaches have contributed to the development of new integrated management models based on the permanent assessment of consumers on the primary attributes and factors that comprise this attraction (Finn and Louviere, 1996; Alemán and Díaz, 2006; Driesener and Romaniuk, 2006).

Based on the foregoing arguments, this study measures the attraction factors integrating a factor denominated herein as design perception and the eco-natural environment. Therefore, the originality of this study lies in two aspects:

(1) the design and eco-natural environment proposal as an attraction factor of shopping centers; and

(2) the consideration of statistical relations between the attraction factors (including the design and the eco-natural environment) and the intention to visit as a dependent variable in a complete structural equation model.

This effect has proved to be of particular importance for commercial management and the attainment of competitive advantage when applied to other fields such as hotels and big stores (Brengman et al., 2012; Rogerson and Sims, 2012; Lee et al., 2010; Kim and Han, 2010).

This study is structured as follows. First, the conceptual framework of these variables and its relations are presented, with the objective of supporting the suggested hypothesis. Thereafter, the used methodology and the results obtained from the structural equation model are described. Finally, the business implication and the future lines of investigation are exposed.

\section{Theoretical review}

Several dimensional typologies can be used to create a model of attraction factors of a shopping center (North and Kotze, 2004). Among these factors, the offer, accessibility, service, and environment variables are always present.

\section{Attraction factors of the shopping centers}

According to Munuera and Cuestas (2006), most international studies have focused on commercial establishments and their individual features; however, these studies have not considered the shopping center as a unit of analysis. Micu (2013) found that various attraction factors of the shopping center are mainly oriented toward the geographical and cultural features of the study. Accordingly, a plurality of attraction factors in the reviewed literature is observed (see Table I).

Ultimately, there is no consensus regarding numerous attraction factors because the variables that constitute them are multiple and may refer to tangible and intangible aspects, which also depend on the subjective assessment of each (North and Kotze, 2004). 


\begin{tabular}{|c|c|c|c|}
\hline Study & $\begin{array}{l}\text { Number of } \\
\text { factors }\end{array}$ & Factors & $\begin{array}{l}\text { Attraction } \\
\text { factors of }\end{array}$ \\
\hline Singh and Prashar (2013) & 5 & $\begin{array}{l}\text { Environment, access, physical environment, offer management, } \\
\text { and security }\end{array}$ & \\
\hline Banerjee (2012) & 9 & $\begin{array}{l}\text { Establishment image, entertainment, access and convenience, } \\
\text { physical environment, security, visitors' lifestyle, time-saving, } \\
\text { architecture, and commercial rewards }\end{array}$ & 201 \\
\hline Sujo and Bharati (2012) & 5 & $\begin{array}{l}\text { Attractiveness, environment comfort, service staff, shopping } \\
\text { easiness, and convenience }\end{array}$ & \\
\hline Hira and Mehvish (2012) & 3 & Inner environment, establishment image, and access easiness & \\
\hline Rajagopal (2009) & 7 & $\begin{array}{l}\text { The shopping center offer, excitement level, promotions, purchase } \\
\text { volume, distance traveled inside the establishment, time employed } \\
\text { in the establishment, and preference for traditional stores. }\end{array}$ & \\
\hline Teller and Reutterer (2008) & 4 & Access, location, visitors, and environment perception & \\
\hline Ahmad (2012) & 6 & $\begin{array}{l}\text { Environment aesthetics, access, and comfort, offer variety, } \\
\text { entertainment, and service quality }\end{array}$ & \\
\hline El-Adly (2007) & 6 & $\begin{array}{l}\text { Comfort, entertainment, offer variety, shopping center features (range, } \\
\text { services, and prices), convenience and access, and luxury perception }\end{array}$ & \\
\hline Khei et al. (2001) & 5 & $\begin{array}{l}\text { Access easiness, offer quality and variety, offer popularity and } \\
\text { luxury, shopping center facilities and environment, and the } \\
\text { presence of diverse commercial incentives }\end{array}$ & \\
\hline Ruiz (1999) & 3 & $\begin{array}{l}\text { Commercial environment and variety, parking and shopping scene, } \\
\text { and staff professionalism }\end{array}$ & \\
\hline Bodkin and Lord (1997) & 4 & $\begin{array}{l}\text { Convenience, existence of a particular store in the shopping center, } \\
\text { services provided, and prices }\end{array}$ & $\begin{array}{r}\text { Table I. } \\
\text { raction factors of }\end{array}$ \\
\hline Source: Own development & & & \\
\hline
\end{tabular}

However, the attraction factor analysis of shopping centers and establishments is conceived as a strategy of competitive distribution to draw more clients to the shopping facilities and improve their experience (Bigné and Andreu, 2004). From this perspective, assessing the attractiveness of the shopping centers is important for the following reasons: to improve its own management due to its relation with the intention to visit (Michon et al., 2005), and to provide information about the relation between attraction factors and consumer profiles, i.e., to give knowledge on the segmentation and specialization of shopping centers based on the understanding of the style of clients' purchasing decisions (Alavi et al., 2016).

\section{Identification of attraction factors and establishment of the hypothesis}

Based on the reviewed literature, six attraction factors are prominent: five traditional dimensions and the sixth one regarding the design and eco-natural environment perceived by visitors. A brief description of each variable with its particular hypothesis is presented, with specific focus on the design and eco-natural environment variable.

Physical environment, cleanliness, and security. Several authors described the importance of physical environment for the visitors behavior within shopping centers (Mehrabian and Russell, 1974; Wakefield and Baker, 1998; Turley and Milliman, 2000; Khei et al., 2001; Bigne et al., 2006; El-Adly, 2007; Ahmad, 2012; Hira and Mehvish, 2012; Sujo and Bharati, 2012; Singh and Prashar, 2013). In sum, physical environment, cleanliness (Ahmad, 2012; Dennis et al., 2002), and security (Hoffman and Turley, 2002) are important factors influencing visitor behavior in shopping centers. Consequently, considering the importance of this feature, the following hypothesis is proposed:

H1. Physical environment, cleanliness, and security positively impact the users' intention to visit the shopping center. 
EJMBE

26,2

According to the previous consideration, the effects of physical environment can transcend when oriented toward design and the use of green or natural spaces as shown in recent studies.

Design and eco-natural environment. The design and eco-natural environment perception of the shopping center is of particular concern in the literature related to environmental and atmospheric features of shopping settings. Do Paço and Raposo (2009) highlighted the importance and influence of the use of ecological elements in commercial settings on the attitudes and intention to visit and buy. In the tourism field, some empirical results exist on the effects of ecological design used in hotels for the attainment of competitive advantage (Lee et al., 2010) and the client's preference for hotels with ecological resources (Rogerson and Sims, 2012; Kim and Han, 2010; Weinmaster, 2009; Ayala, 1995).

In the commercial field, Brengman et al. (2012) proved that the incorporation of spaces with vegetation impacts shopping behavior and emotions. Furthermore, the environmental design of commercial settings oriented toward the consumption and lifestyle in natural spaces favors the relation between the environment and their well-being (Amérigo et al., 2013; Herzog and Strevey, 2008). According to Bigne et al. (2006), the creation of an enjoyable environment becomes the objective in the distribution to improve the consumers' shopping experience. Additionally, Amérigo et al. (2013) highlighted the increasing interest in researching this area regarding the proenvironmental conduct and the analysis of the individual's attitudes toward the environment (Amérigo et al., 2007; Chebat and Michon, 2003). Therefore, the following hypothesis is proposed:

H2. Design and eco-natural environment perception of the shopping center positively impacts the users' intention to visit the shopping center.

Mobility and accessibility. Some authors considered mobility and accessibility of the shopping center to be more important than attractiveness (Khei et al., 2001; De Juan, 2004; El-Adly, 2007; Teller and Reutterer, 2008; Rajagopal, 2009; Ahmad, 2012; Banerjee, 2012; Hira and Mehvish, 2012). Thus, people look for comfortable, cozy, and convenient commercial establishments or shopping centers. Therefore, the following hypothesis is proposed:

H3. Mobility and accessibility of the shopping center positively impact the users' intention to visit the shopping center.

Additionally, mobility and accessibility features as attraction factors can be favored by different services offered in the field of amusement and entertainment. These features comprise the following variable.

Additional services and entertainment. Studies have indicated that shopping centers have improved their own image and attractiveness due to the inclusion of other services such as food, relaxation, and entertainment services (Bellenger et al., 1977; Haynes and Talpade, 1996; De Nisco and Rosaria Napolitano, 2006; El-Adly, 2007; Ahmad, 2012; Sit and Birch, 2014). This can be considered to be a favorable offer for leisure, constituted by diverse factors influencing attendance motivations (Sit et al., 2003). Therefore, this ensemble of features allows us to propose the following hypothesis:

H4. Additional services and entertainment positively impact the users' intention to visit the shopping center.

Offer variety, quality, and status. Offer variety, quality, and status have been a traditional attraction issue of the shopping centers (Frasquet, 2000; Khei et al., 2001; Singh and Prashar, 2013). Boatwright and Nunes (2001) suggested that consumer preferences are influenced by the perception of variety within an ensemble of selection choices. Different authors highlighted the importance for clients to count on a wide supply of products (Más Ruiz, 1999; 
Khei et al., 2001; Suárez et al., 2007), especially when comparing prices and quality (El-Adly, 2007) to optimize the visit experience (Singh and Prashar, 2013). In this respect, Khei et al. (2001) considered that the quality and variety variables are the most critical attributes to the measure of attraction factors of shopping centers. On the other hand, the status attribute is also connected to the offer variety and quality (Hollander, 1960; Gould et al., 2005), which also influences the visit experience (Kim, 2001). Consequently, this ensemble of features allows to establish the following hypothesis:

Attraction factors of shopping centers

H5. The offer variety, quality, and status of the shopping center positively impact the users' intention to visit the shopping center.

\section{Methodology}

The empirical study adopts a quantitative, descriptive, and casual approach, and its geographical scope is framed in Bogota, Colombia.

\section{Survey and sample}

The study of the relationships raised and the empirical contrast of the hypothesis was performed using a sample of visitors aged above 18 years. Personal interviews with a structured questionnaire were conducted at the shopping center, where surveyed individuals were located, at different hours and days of the week. The gender, age, educational level, and shopping center variables were considered. The selection procedure of the sample was not probabilistic. Specifically, surveys were conducted for convenience.

The personal surveys were conducted by a group of surveyors who were specially trained for the task; furthermore, 449 valid questionnaires were obtained in the 25 studied shopping centers that were classified as follows according to the International Council of Shopping Centers: 58 interviews correspond to the urban commercial gallery format, 63 to the small shopping center, 58 to the medium shopping center, 161 to the big shopping center, 50 to the specialized center (also called manufacturer thematic center), and finally 59 to hypermarket-based center. All shopping centers belong to the Shopping Center Association in Colombia: Acecolombia (www.acecolombia.org), with the geographical scope being Bogota, guaranteeing that the shopping centers were establishments with commercial locations, that these were recognized and longstanding in the market, and that these were adequately distanced geographically one from another.

The sample profile can be observed in Table II.

\section{Measurement instrument}

For the creation of the questionnaire, the traditional dimensions used and described previously in the theoretical body were analyzed. As a pretest, different propositions were formulated and measured in a Likert scale with five answer levels, with 1 being totally in disagreement and 5 being totally in agreement. In the pilot phase, 60 interviews to clients were conducted and, as a result, propositions with less contribution levels were eliminated. The initial 51 schemes were reduced to 27 . Table II presents the indicators posed in the questionnaire.

Subsequently, as a data processing technique and based on the research objectives, the conductive analysis to prove the model was performed.

\section{Independent and dependent factors and their measure}

The independent model factors, as described in the establishment of hypothesis, are offer variety, quality, and status; mobility and accessibility; additional services and entertainment; 
EJMBE

26,2
Classification data

Gender

Male

Female

Age (years)

18-24

25-32

33-40

41-50

More than 50

Educational level

Elementary school

Middle school

Technician

Table II.

Sample

characterization

Professional

Postgraduate
47.7

52.3

39.2

20.7

12.2

13.3

14.3

2.9

17.8

14.3

55

10

Source: Own development

physical environment, cleanliness, security, and information; and design and eco-natural environment. Their composition is described as follows.

Offer variety, quality, and status. This factor includes measures related to products and brands available in the shopping center and comprises six items. The items used include offer and store variety as well as the presence of well-known brands, a variety of store products and brands, quality of the products, and presence of exclusive and prestigious clothing brands.

Mobility and accessibility. This factor includes measures related to accessibility and mobility for people inside the shopping center and comprises five items. The questions used focused on measuring the freedom of movement and orientation in the shopping center, the perception of available space for walking, and the ease of access and comfort while shopping in the stores and the shopping center.

Additional services and entertainment. This factor includes measures related to food services, movies, relaxation, and the price-quality relation of such services. It comprises five items.

Physical environment, cleanliness, security, and information. This factor includes measures related to the perception of the physical environment and cleanliness inside the shopping center, including the perception of safety, data points, and air quality. It comprises five items.

Design and eco-natural environment. This factor includes measures related to space disposition and natural settings with vegetation, and it comprises four items. The questions used focused on measuring the perception of natural scenarios, the presence of settings with vegetation, the eco-environmental design of the shopping center, and the perception of using an architecture that includes natural materials.

The dependent model factor, which expresses the attractiveness to visit, has been denominated as the intention to visit. Such concept belongs to the area of future behavioral intentions (Dwyer et al., 1987; Robert and John, 1982; Wakefield and Baker, 1998; Bigné and Andreu, 2004) and describes the peoples' desire to visit the shopping center (Iturriagagoitia and de Madariaga, 2010; Anselmsson, 2006). This factor, intention to visit, includes measures related to the probability of visiting a shopping center. It comprises two items oriented to measure the preference to visit and the enjoyment of and motivation for visiting the shopping center. The content of the questions expresses the will of the users to visit and frequent the shopping center, modulating the purpose of the assessed dimension. 


\section{Results}

The dependent factor or intention to visit and the independent factors with a potential relation with it were identified. Subsequently, the convergent validity and the discriminant validity of the scales were analyzed by calculating the corresponding composite reliability $(\mathrm{CR})$, the average variance extracted (AVE), and the discriminant matrix through partial least squares (PLS) (Hair et al., 2006). Finally, the relations between the endogenous and exogenous latent variables were analyzed to validate the structural equation model defined previously, using the statistical package AMOS 23.0 from IBM.

\section{Preliminary analysis}

To find the underlying structure of the factors and examine the multidimensionality of the measurement instrument, an exploratory study was conducted on SPSS v22. To detect if the items would precisely measure each factor, all dependent and independent variables were included in the factorial analysis. Bartlett's sphericity test was significant $\left(\chi^{2}=6,580,318\right.$, $\mathrm{gl}=351, p<0.001$ ). The Kaiser-Meyer-Olkin's sampling adequacy measure of 0.903 exceeds the minimum limit of 0.50 proposed by Kaiser (1974). During the factorial analysis, six factors with individual values higher than 1.0 were identified, which explains 65.8 percent of the variance and which exceeds the limit of 45 percent recommended by Netemeyer et al. (2003). The out coming solution was interpreted to apply a varimax rotation (see Table III).

\begin{tabular}{|c|c|c|c|c|c|c|}
\hline & \multicolumn{6}{|c|}{ Components } \\
\hline & 1 & 2 & 3 & 4 & 5 & 6 \\
\hline Presence of well-known brands stores & 0.797 & & & & & \\
\hline The offer of exclusive and prestigious clothing brands & 0.787 & & & & & \\
\hline Variety in available stores & 0.750 & & & & & \\
\hline Variety in offer and merchandise & 0.726 & & & & & \\
\hline Quality of displayed products & 0.655 & & & & & \\
\hline Feeling of status & 0.625 & & & & & \\
\hline Natural spaces or scenarios & & 0.898 & & & & \\
\hline Presence of settings with vegetation & & 0.894 & & & & \\
\hline Design and eco-natural environment of the shopping center & & 0.885 & & & & \\
\hline Use of natural materials in the architecture & & 0.847 & & & & \\
\hline Freedom of movement inside the shopping center & & & 0.797 & & & \\
\hline Available space for walking & & & 0.711 & & & \\
\hline Easy access to the shopping center & & & 0.693 & & & \\
\hline Easy orientation when walking in the shopping center & & & 0.542 & & & \\
\hline Comfortable commercial establishment to shop & & & 0.311 & & & \\
\hline Restaurants and cafeterias availability & & & & 0.840 & & \\
\hline Food court availability & & & & 0.807 & & \\
\hline Movie theater availability & & & & 0.543 & & \\
\hline Good relationship between price and quality of product and services & & & & 0.472 & & \\
\hline Relaxation areas availability (chairs, sofas) & & & & 0.313 & & \\
\hline Air quality inside the shopping center & & & & & 0.392 & \\
\hline Look and cleanliness of the bathrooms & & & & & 0.782 & \\
\hline Security level perceived in the shopping center & & & & & 0.642 & \\
\hline Cleanliness and order inside the shopping center & & & & & 0.632 & \\
\hline Point of information availability & & & & & 0.387 & \\
\hline Frequency attendance & & & & & & 0.539 \\
\hline Enjoyment when frequenting the shopping center & & & & & & 0.538 \\
\hline
\end{tabular}

Notes: Extraction method: main component analysis; rotation method: Varimax with Kaiser normalization; rotation convergence in 8 iterations. Total of explained variance: 65.849 percent; $\mathrm{KMO}=0.903$. Bartlett's sphericity test: 6,580,318; 351 df. $p<0.001$

Table III.

Exploratory factorial analysis 
EJMBE

26,2

206

The intention to visit factor (4.6 percent) comprises two items with acceptable loads. The offer, quality, and status variety factor (17.4 percent) comprises six items with higher loads. The design and eco-natural atmosphere factor (14.6 percent) comprises four variables with high factorial loads in the matrix of rotated components. The mobility and accessibility factor (11.6 percent) comprises five variables. Among these, the variable of comfort while shopping, which should be included in the offer variety factor was included in the mobility factor due to its comfort definition. The additional services and entertainment factor (8.9 percent) comprises five items related to food, movies, the quality-price relation of these services, and relaxation areas. This last variable was associated with this dimension due to its definition. Apparently, the load was not high (0.3). However, considering the sample size, it was considered to be enough. Finally, physical atmosphere, cleanliness, security, and information factor (8.7 percent) comprises five items related to such variables along with the air quality.

\section{Model and data adequacy}

For the model adequacy, a traditional structural equation approach was adopted for a reflective measurement model (Valdivieso, 2013; Henseler et al., 2009; Bollen, 1989) by following the steps suggested in the literature (Hair et al., 2011; Díaz et al., 2010; Kline, 2005).

The primary concern for data processing relates to the size of the sample depending on the number of relations to be assessed. Chin's widely used golden rule states that the sample size must be 10 times greater than any of these two alternatives latent variable or factor with the largest number of indicators or dependent variable with the most significant number of independent variables influencing it.

In our model, the first possibility equals six (product variety, quality, and status), while the second one equals five (the number of arrows closer to the intention to visit). Therefore, the minimum sample size is $6 \times 10=60$, and our sample contains 449 cases. Additionally, the power test for the dependent variable (R2) for the case with five predictors, $\alpha=0.005$, and a moderate effect size of 0.15 were calculated. The minimum level for social sciences is 0.8 (Cohen, 1988). Results revealed a statistical power $(1-\beta)$ above 0.95 .

\section{Reflective model assessment: PLS measurement instrument validity and reliability}

Regarding convergent validity, bootstrapping technique with no sign change was used for more than 5,000 samples. Then, results with a sign change and individual changes were compared to the constructs. Significance testing at a 0.05 level was used. Results were consistent across the three methods; with the exception of two indicators (see below), no similar charges or charges below 0.06 were obtained.

This is the usual criteria when assessing the existence of convergent validity of indicators of the reflective constructs. Our case included the following: variety, quality, supply, and status (C1); eco-natural environment and design (C2); mobility and accessibility (C3); additional services and entertainment (C4); and physical environment, maintenance, security, and information (C5). Indicators with a load of above 0.7 were acceptable (Carmines and Zeller, 1979) though some authors suggested a lower limit (around 0.6) (Bagozzi and Yi, 1988). Regarding formative constructs - the intention to visit (C6) - validity was assessed from the weights, with statistical significance criteria, instead of size and absence of multicollinearity (Chin, 1998).

As shown in Table IV, all indicators load above 0.7 within their respective reflective constructs, except for two indicators that load below 0.6. They are rest area availability $(0.557)$ and information point availability $(0.600)$. Both signs were removed from the analysis. Furthermore, an analysis on the cross-loadings of indicators with all latent variables did not show any sign that needed a change in its construct.

Construct reliability was evaluated through two indicators: Cronbach's $\alpha(\mathrm{CA})$ and the common criteria, equal to or above 0.7, by Nunnally and Bernstein (1994) and CR 


\begin{tabular}{|c|c|c|c|c|c|c|c|c|}
\hline \multirow[b]{2}{*}{ Indicator } & \multirow[b]{2}{*}{$\mathrm{C} 1$} & \multicolumn{3}{|c|}{ Loading } & \multirow[b]{2}{*}{$\mathrm{C} 5$} & \multirow{2}{*}{$\begin{array}{l}\text { Weight (FIV) } \\
\text { C6 }\end{array}$} & \multirow{2}{*}{$\begin{array}{c}t \text {-value } \\
\text { (bootstrapping) }\end{array}$} & \multirow{2}{*}{$\begin{array}{l}\text { Attraction } \\
\text { factors of }\end{array}$} \\
\hline & & $\mathrm{C} 2$ & $\mathrm{C} 3$ & $\mathrm{C} 4$ & & & & \\
\hline Well-known stores & 0.799 & & & & & & $38.429 *$ & \\
\hline Exclusive clothing & 0.793 & & & & & & $37.761^{*}$ & \\
\hline Variety of stores & 0.778 & & & & & & $34.871^{*}$ & \\
\hline Variety of the offer and merchandise & 0.746 & & & & & & $27.695^{*}$ & \\
\hline Quality of exhibited products & 0.791 & & & & & & $39.861^{*}$ & 208 \\
\hline Sensation of status & 0.764 & & & & & & $32.813^{*}$ & \\
\hline Natural spaces or scenarios & & 0.909 & & & & & $76.774^{*}$ & \\
\hline Environments with vegetation & & 0.911 & & & & & $87.584^{*}$ & \\
\hline Eco-environmental design & & 0.923 & & & & & $113.02 *$ & \\
\hline Architecture integrating natural elements & & 0.897 & & & & & $76.400^{*}$ & \\
\hline $\begin{array}{l}\text { Easy access and movement within the } \\
\text { shopping center }\end{array}$ & & & 0.766 & & & & $25.836^{*}$ & \\
\hline Space for walking & & & 0.647 & & & & $14.968^{*}$ & \\
\hline Easy access to the Shopping Center & & & 0.686 & & & & $17.786^{*}$ & \\
\hline Suitable orientations & & & 0.712 & & & & $22.915^{*}$ & \\
\hline Comfortable stores & & & 0.730 & & & & $24.040 *$ & \\
\hline Availability of restaurants and cafes & & & & 0.832 & & & $36.941 *$ & \\
\hline Availability of food areas & & & & 0.836 & & & 40.929* & \\
\hline Availability of movies & & & & 0.669 & & & $16.376^{*}$ & \\
\hline $\begin{array}{l}\text { Good quality/price relationship of } \\
\text { products and services }\end{array}$ & & & & 0.734 & & & $22.245^{*}$ & \\
\hline Air quality & & & & & 0.702 & & $21.666^{*}$ & \\
\hline Bathroom maintenance & & & & & 0.684 & & $18.043^{*}$ & \\
\hline Perceived level of security & & & & & 0.776 & & $33.270 *$ & \\
\hline Cleanliness and maintenance & & & & & 0.772 & & $25.586^{*}$ & \\
\hline Frequent visitor** & & & & & & $0.298(2.394)$ & $3.576^{*}$ & \\
\hline Likeness to visit the shopping center & & & & & & $0.754(2.394)$ & $10.156^{*}$ & Loadings and weights \\
\hline $\begin{array}{l}\text { Notes: } * t \text { significant value for } p<0.001 \text {; } \\
6 \text { is significant at } 0.01 \text { level, which is why } \\
\text { the sense of the construct }\end{array}$ & $\begin{array}{l}* * \text { *the c } \\
\text { his item }\end{array}$ & $\begin{array}{l}\text { orrelat } \\
\text { h has b }\end{array}$ & $\begin{array}{l}\text { tion bet } \\
\text { seen kep }\end{array}$ & $\begin{array}{l}\text { ween } t \\
\text { tin th }\end{array}$ & $\begin{array}{l}\text { the two } \\
\text { e forma }\end{array}$ & $\begin{array}{l}\text { items that ma } \\
\text { ation of the fact }\end{array}$ & $\begin{array}{l}\text { ke up component } \\
\text { or in coherence to }\end{array}$ & $\begin{array}{l}\text { of indicators in the } \\
\text { model's reflective and } \\
\text { formative constructs }\end{array}$ \\
\hline
\end{tabular}

(Werts et al., 1974; Fornell and Larcker, 1981) for reflective constructs (Chin, 1998). For CR, results around 0.6 were acceptable (Bagozzi and Yi, 1988). Hair et al. (2012) suggested that assessing both criteria, CA and CR are good alternatives. As shown in Table IV, all constructs were above the minimum limits for $\mathrm{CA}=0.7$ and $\mathrm{CR}=0.60$. These authors also suggested a minimum AVE limit of 0.5 as a measure of convergent validity between reflective constructs, which was achieved by all constructs. Fornell and Larcker (1981) recommended an additional verification on the subject of discriminant validity: the square root of AVE must be bigger than the correlations between latent variables; this is accomplished by the results (see Table V). Moreover, a hetero trait-mono trait (HTMT) study (Henseler et al., 2015) was conducted to assess discriminant validity. All HTMT ratios in absolute value were below the 0.90 limit, indicating that discriminant validity is present between all the pairs of reflective constructs.

\section{Relation between factors of attraction and the intention to visit shopping centers}

The assessment and construction of the structural model were conducted using the AMOS software by using ordinal variables, as exposed before, without the need to fulfill the multivariate normality assumption. Bollen (1989) and Jöreskog and Sörbom (1996) recommended using polychoric correlations together with the weighted estimates and generalized least squares estimates. To evaluate the fit of the model, the $\chi^{2}$ ratio to the 
EJMBE

26,2

208

degrees of freedom (CMIN/DF), the corresponding adjustment index, the goodness of fit index (GFI), and the adjusted goodness of fit index (AGFI) were suggested. About residuals, the RMSEA mean squared error was proposed, as described below.

\section{Initial model adjustment}

First, the maximum likelihood estimation technique was used. Specific indicators showed adjustment difficulties $(\mathrm{CMIN} / \mathrm{DF}=6.203, \mathrm{GFI}=0.740, \mathrm{AGFI}=0.687, \mathrm{RMSEA}=0.108)$. With these model fit indicators and given that the multivariate normality assumption is not satisfied, the generalized least squares method was used instead. The following values were obtained for indicators: $\mathrm{CMIN} / \mathrm{DF}=2.843$; $\mathrm{GFI}=0.863$, $\mathrm{AGFI}=0.835$, RMSEA $=0.064$; these results led to a re-specification of the previous model.

\section{Model re-specification}

Finally, some observable variables correlating with other exogenous latent variables were found and deleted for the model's fit, as shown in Figure 1.

The a priori model shows a causal relation among exogenous variables, supply, design and eco-natural environment, mobility and accessibility, entertainment and services, and physical environment with the endogenous variable of intention to visit. However, based on the studies by Suárez (2016) and El-Adly (2007), the respecified model considers no relation between factors such as mobility and accessibility and entertainment and additional services with the intention to visit. Similarly, based on the results obtained by Hira and Mehvish (2012) regarding the importance of the accessibility and mobility variable, indirect effects of the variables supply, design and eco-natural environment, entertainment and services, and physical environment were proposed through the latent variable mobility and accessibility.

\section{Goodness of fit measures of the respecified model}

As mentioned before, there are different indexes to guide the goodness of fit using the SEM technique and, more specifically, using covariances. In addition, given the diverse implications and complexities of this process, different values are proposed to make a decision regarding the validity of the structural model (Kerlinger and Lee, 2002). This approach seems to be flexible in the limit values suggested by experts.

For this study and after some model adjustments, the following value was obtained for the most common indicators: $\mathrm{CMIND} / \mathrm{GL}=1.885$. Schumacker and Lomax (2004) suggested that values below 3 are acceptable; $\mathrm{GFI}=0.958$ and $\mathrm{AGFI}=0.933$. Browne and Cudeck (1993) suggested that values greater than 0.90 are acceptable. Finally, the RMSE, which represents the square root mean or residual covariance mean, was analyzed; in this indicator, 0 represents a perfect fit, but the maximum is unlimited. According to some researchers, RMSE must be below 0.08 (Browne and Cudeck, 1993); ideally, it must be below 0.05 (Steiger, 1990).

Table V.

Reliability of convergent and discriminant validity analysis of constructs with PLS

\begin{tabular}{lccccccccc}
\hline & \multicolumn{8}{c}{$\begin{array}{c}\text { Correlations matrix - Fornell } \\
\text { Larcker criteria }\end{array}$} \\
\hline Physical environment, maintenance and security & 0.718 & 0.824 & 0.540 & 0.735 & & & \\
Design and eco-natural environment & 0.931 & 0.951 & 0.828 & 0.293 & 0.910 & & \\
Mobility and access & 0.760 & 0.835 & 0.503 & 0.594 & 0.284 & 0.709 & \\
Additional services and entertainment & 0.773 & 0.853 & 0.594 & 0.411 & 0.312 & 0.435 & 0.771 \\
Product variety, quality and status & 0.871 & 0.902 & 0.606 & 0.470 & 0.239 & 0.563 & 0.570 & 0.779 \\
Intention to visit & - & - & - & 0.489 & 0.392 & 0.506 & 0.442 & 0.610 \\
& & & & & & & & &
\end{tabular}




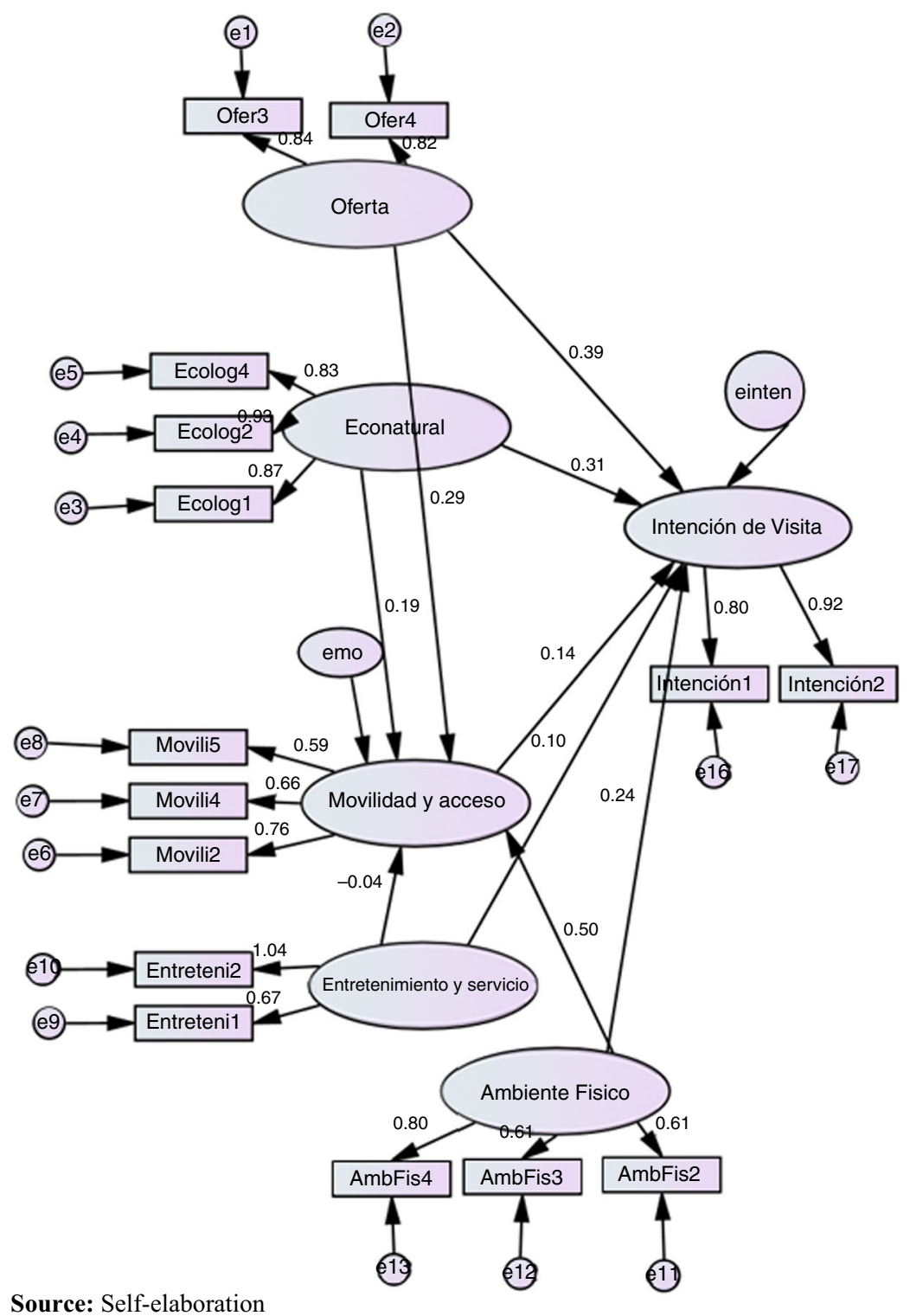

Attraction factors of shopping centers

Figure 1.

Model re-specification of shopping center's attraction factors

Alternatively, RMSE's maximum confidence interval should not exceed 0.08 (Hu and Bentler, 1998), in this case, the range was found to be between 0.032 and 0.055 , where $\mathrm{RMSE}=0.044$, satisfying the values suggested by the experts.

\section{Parameter estimation}

The estimated results for latent variables are presented below. Although an adequate adjustment can be performed, this does not necessarily imply a good relation between the studied variables. Estimators of the relations between the different exogenous and 
EJMBE 26,2

\section{0}

Table VI.

Estimators and their importance for endogenous and exogenous latent variables endogenous variables as well as their respective standard error, standardized estimate (C.R), and $p$-values are presented in Table VI.

Table VI shows that the intention to visit is significantly affected by latent variables, supply, design and eco-natural environment, and physical environment; mobility and accessibility $(p<0.225)$ and entertainment and services $(p<0.885)$ do not significantly influence the dependent variable intention to visit, as discussed above in the model re-specification.

Other important relations between latent variables were also detected. Thus, the mobility and accessibility variable is significantly influenced by design and eco-natural environment, physical environment, and supply variables. Furthermore, entertainment and additional services variable are close to statistical significance $(p<0.054)$. Table VII shows the relation between the exogenous variables and their constructs. Thus, the first column shows non-standardized estimates of the relations between the variables on the right compared with the ones of the left. When the estimation value equals 1 , it indicates that this restriction was placed in one of the equations in all latent variables to calculate the model's structural relation.

Therefore, exogenous latent variables are measured with the following items, all of which are statistically significant:

- supply and variety: variety of available shops, offer, and/or merchandise;

- design and eco-natural environment: natural spaces or scenarios and environments with vegetation and architecture;

\begin{tabular}{|c|c|c|c|c|}
\hline Relations & Estimations & SE & $\mathrm{CR}$ & $p$ \\
\hline Mobility and access $\leftarrow$ entertainment and services & -0.102 & 0.053 & -1.928 & 0.054 \\
\hline Mobility and access $\leftarrow$ design and eco-natural environment & 0.136 & 0.034 & 3.979 & 0.001 \\
\hline Mobility and access $\leftarrow$ physical environment & 0.472 & 0.076 & 6.213 & 0.001 \\
\hline Mobility and access $\leftarrow$ offer & 0.205 & 0.055 & 3.697 & 0.001 \\
\hline Intention to visit $\leftarrow$ offer & 0.420 & 0.075 & 5.572 & 0.001 \\
\hline Intention to visit $\leftarrow$ design and eco-natural environment & 0.276 & 0.047 & 5.939 & 0.001 \\
\hline Intention to visit $\leftarrow$ physical environment & 0.371 & 0.113 & 3.297 & 0.001 \\
\hline Intention to visit $\leftarrow$ mobility and access & 0.151 & 0.124 & 1.214 & 0.225 \\
\hline Intention to visit $\leftarrow$ entertainment and services & -0.010 & 0.071 & -0.144 & 0.885 \\
\hline Intention $2 \leftarrow$ intention to visit & 1.000 & & & \\
\hline Intention $1 \leftarrow$ intention to visit & 0.979 & 0.060 & 16.368 & 0.001 \\
\hline
\end{tabular}

Table VII.

Estimators and their importance for exogenous latent variables from observations

\begin{tabular}{|c|c|c|c|c|}
\hline Relations & Estimation & $\mathrm{SE}$ & $\mathrm{CR}$ & $p$ \\
\hline Ofer3 $\leftarrow$ offer & 1.063 & 0.094 & 11.361 & $0.001^{*}$ \\
\hline Ofer $4 \leftarrow$ offer & 1.000 & & & \\
\hline Ecolog $4 \leftarrow$ Design y Eco-natural environment & 1.000 & & & \\
\hline Ecolog $2 \leftarrow$ Design y Eco-natural environment & 1.043 & 0.045 & 23.254 & $0.01 *$ \\
\hline Ecolog1 $\leftarrow$ Design y Eco-natural environment & 0.989 & 0.046 & 21.542 & $0.001^{*}$ \\
\hline Movili5 $\leftarrow$ mobility and access & 1.000 & & & \\
\hline Movili4 $\leftarrow$ mobility and access & 0.963 & 0.102 & 9.408 & $0.001 *$ \\
\hline Movili2 $\leftarrow$ mobility and access & 1.160 & 0.114 & 10.148 & $0.001^{*}$ \\
\hline Entreteni $2 \leftarrow$ entertainment and services & 1.163 & 0.113 & 10.324 & $0.001 *$ \\
\hline Entreteni1 $\leftarrow$ entertainment and services & 1.000 & & & \\
\hline AmbFis $4 \leftarrow$ physical environment & 1.000 & & & \\
\hline AmbFis $3 \leftarrow$ physical environment & 0.901 & 0.082 & 10.932 & $0.001^{*}$ \\
\hline AmbFis $2 \leftarrow$ physical environment & 0.950 & 0.087 & 10.858 & $0.001 *$ \\
\hline Intencion $2 \leftarrow$ intention to visit & 1.000 & & & \\
\hline Intencion $1 \leftarrow$ intention to visit & 0.979 & 0.060 & 16.368 & $0.001^{*}$ \\
\hline
\end{tabular}

Note: *Significant at $p<0.05$

Source: Self-elaboration 
- mobility and accessibility: freedom of motion within the shopping center, ease of access to the shopping center, and precise orientations for walking areas;

- entertainment and services: availability of restaurants and cafes as well as food areas;

Attraction factors of shopping centers

- physical environment: appearance and cleanliness of the bathroom areas, perceived level of security of the shopping center, and cleanliness and order inside the shopping center; and

- in a view to explain the endogenous variable intention to visit, the following item was also considered: possible frequent visitor.

\section{Discussion}

Assessing a shopping center's attractiveness is crucial as this aspect is closely related to the intention to visit (Michon et al., 2005). Measuring attraction factors is fundamental for companies developing their economic activity in highly competitive markets such as retail distribution (Munuera and Cuestas, 2006). However, these factors are rather diverse, and there is no agreement regarding quality and typology (North and Kotze, 2004). Such factors are formulated and analyzed according to the objectives of each study, which can be categorized in the research lines of supply/offer, accessibility, services, and environmental components, as noted in the literature review.

Consequently, results obtained from the proposed structural model show a good overall adjustment, and their psychometric properties meet the criteria accepted in the marketing literature. These results support the existence of discriminant validity between shopping centers' attraction factors and, consequently, the validity of most of the proposed working hypotheses, especially when demonstrating the structural relation between design and eco-natural environment and the intention to visit, the main contribution of this study. The implications of each theory are discussed below.

Acceptance of $H 1$ corresponds to previous findings regarding the positive and moderately significant contribution of physical environment to the consumer's intention to visit shopping centers (Biehl-Missal and Saren, 2012; Bigne et al., 2006; Sierra et al., 2000). The perceived safety indicator articulated in this dimension was already formulated by Berman and Evans (1995) when discussing the need to include this type of environmental variables in the study of the shopping centers' attraction factors. Additionally, they suggested that including the human component, employee appearance and the use of uniforms are two variables that can favor the perception of security. In our opinion, the presence of uniformed employees (security, attention, and maintenance employees) inside the shopping center, added to the appearance of the visitors themselves, are relevant variables regarding physical environment. International publications support the influence of physical environmental variables on consumer's opinion and buying behavior (Jha and Singh, 2014; Mishra et al., 2014).

Regarding the acceptance of $H 2$, which is the main contribution of this research, we verified the significant and positive effect of design and eco-natural environment on the intention to visit. This factor is a consequence of the visitors' interest toward the environment. Thus, aspects such as the display of vegetation, architecture with natural elements, natural spaces or scenarios, and the perception of eco-environmental design influence the attractiveness factor, which motivates customers to return and become frequent visitors. Maximization of the visitor's experience through environmental resources was suggested by Dewey (1922), who believed that there must be an interrelation between human beings and their environment. Specifically, the study of this variable or factor has a particular influence on consumer experience and behavior (Amérigo et al., 2013; Brengman et al., 2012; Do Paço and Raposo, 2009), which makes it a valuable resource in the 
EJMBE

26,2

212

field of commerce. Furthermore, the literature indicates that the design and composition of the ecological-commercial environment is an important research topic (Söderlund and Newman, 2015; Dover, 2015; Brengman et al., 2012). This demonstrates the need for more empirical works to prove their influence.

It was not possible to empirically prove $H 3$, concerning the relations between mobility and accessibility with the intention to visit, and $H 4$, regarding the relation between entertainment and additional services factor and the intention to visit. Obtained results do not directly confirm these relations; nevertheless, the adjusted model allows to evidence indirect effects of the offer/supply, design and eco-natural environment, entertainment and services, and physical environment variables through the mobility and accessibility variable. That is, obtained results suggest that the accessibility and mobility construct mediates or moderates the effects of each of the attraction factors on the intention to visit, an issue that needs to be confirmed or dismissed in future research as it had not been considered in the initial conceptual framework.

$H 5$, regarding the positive effect of variety, quality, and status of the shopping center, was proved to be most significant while considering shopping center's attractiveness. These effects have been discussed by different authors (Khei et al., 2001; Gould et al., 2005; Rajagopal, 2009) who consider supply/offer quantity and quality, including available stores and brands, to be fundamental elements regarding the shopping center's attractiveness. Kim (2002) also discussed the relations of the characteristics of the offer with the social value for the consumer, which can mold the preference and behavior of consumers toward the shopping center in accordance with the dominant image of sophistication associated with it (Michon et al., 2015). In our opinion, shopping centers do not only have an offer based on the quantity, variety, and quality of the articles and services delivered but also suggest images or perceptions of status from the brands marketed in these spaces.

\section{Conclusions, limitations, and future research lines}

Park (2016), Baker and Wakefield (2012), and Howard (1997) considered that shopping centers are, by definition, spaces with a high level of design of the commercial environment. In this case, as evidenced in the results of this research, consumer behavior is influenced by variables that can be understood from the field of study of environmental psychology as it deals with the relation between human behavior and physical environment (Dewey, 1922; Mehrabian and Russell, 1974; Heimstra and McFarling, 1978; Kaplan and Kaplan, 1989; Kaplan, 1995). Meanwhile, Jiménez et al. (2015), Amérigo et al. (2013), Suárez and Gumiel (2012), and Herzog and Strevey (2008) suggested that environmental psychology analyzes the influence of environmental, physical stimuli on human behavior.

Park (2016) stated that people visit shopping centers for several reasons such as buying the product they need or enjoying the shopping center's atmosphere and environment. In this sense, shopping centers compete for customers' attention; thus, they must allow for memorable experiences, with attraction variables favoring sensations, feelings, cognitive, and emotional responses associated with the experience of each shopping center (Brakus et al., 2009; Srinivasan and Srivastava, 2010). In this manner, a particular consumer response and an increase in the purchase probability can be achieved (Spence et al., 2014; Turley and Milliman, 2000; Kotler, 1973).

With regard to business implications, identification of specific empirical findings related to the way attraction factors work allows marketing directors and managers to improve their management decisions concerning design and implementation of marketing strategies, tactical decision guidance, decision-making assessment or control, and the proposal of alternative positioning attributes, such as the design, management, and arrangement of eco-natural environments that allow to increase the number of visits and purchases within these establishments. 
The main conclusion of this study was to empirically include and demonstrate the influence of design and natural eco-environment on the intention to visit, along with other elements considered in previous investigations. This effect highlights the need to consider the relations among shopping centers' design, environment and ecological architecture, and consumers' behavior. In this sense, the literature provides a research line regarding the effect of biophilic architecture, which suggests that people need to be in permanent contact with ecological or natural spaces (Beatley, 2011; Appleton, 1975). These spaces or environments offer multiple psychological, social, environmental, economic, leisure, and production benefits (Söderlund and Newman, 2015).Therefore, the design of ecological spaces and environments has the potential of becoming a field of interest for the commercial management of shopping centers, given its potential effect on visiting and shopping intentions (Wolf, 2005; Joye et al., 2010). This is particularly because it provides favorable effects on positive emotional states such as pleasure and well-being (Brengman et al., 2012).

We believe that given the limitations of this research, a generalization of our results should be made with caution. No further information on the treatment of this attraction factor regarding shopping centers was observed throughout the literature review conducted in this study. Therefore, findings and implications need to be examined in future research. Additionally, although the sample and sample units are considered to be large enough for Bogota, the sample is not random. Furthermore, this population does not represent all customers or users of different types of shopping centers, all customer profiles, or all possible geographical locations, segmentation, and specialization issues that were not considered in the search.

However, despite these limitations, we consider that this study provides relevant information to the body of knowledge about the commercial management of retail establishments and their attraction factors. In this light, it would be interesting to include information that compares the relation between design and green environment with the consumer's emotional states in future studies, given the limited information found in the literature. It would also be important to further expand the study of the relation between the attraction factors and the profiles of current and/or potential consumers. Finally, we recommend including hierarchical questions to relate attraction factors to visitor profiles, geo-demographic information, and format typology of the establishment for possible multigroup analysis according to size, supply, and proximity criteria.

\section{References}

Ahmad, A.E.M.K. (2012), "Attractiveness factors influencing shoppers' satisfaction, loyalty, and word of mouth: an empirical investigation of Saudi Arabia shopping malls", International Journal of Business Administration, Vol. 3 No. 6, pp. 101-112.

Alavi, S.A., Rezaei, S., Valaei, N. and Wan Ismail, W.K. (2016), "Examining shopping mall consumer decision-making styles, satisfaction, and purchase intention", The International Review of Retail, Distribution and Consumer Research, Vol. 26 No. 3, pp. 272-303.

Alemán, J.L.M. and Díaz, P.J.C. (2006), "Factores de atracción de los Centros Comerciales en España", Información Comercial Española, ICE: Revista de economia, Enero-Febrero No. 828, pp. 99-116.

Amérigo, M., García, J.A. and Sánchez, T. (2013), "Actitudes y comportamiento hacia el medio ambiente natural. Salud medioambiental y bienestar emocional”, Universitas Psychologica, Vol. 12 No. 3, pp. 845-856.

Amérigo, M., Aragonés, J.I., de Frutos, B., Sevillano, V. and Cortés, B. (2007), "Underlying dimensions of ecocentric and anthropocentric environmental beliefs", The Spanish Journal of Psychology, Vol. 10 No. 1, pp. 97-103.

Anselmsson, J. (2006), "Sources of customer satisfaction with shopping malls: a comparative study of different customer segments", The International Review of Retail, Distribution and Consumer Research, Vol. 16 No. 1, pp. 115-138. 
EJMBE 26,2

Appleton, J. (1975), The Experience of Landscape, Wiley, London.

Ayala, H. (1995), "Ecoresort: a 'green' masterplan for the international resort industry", International Journal of Hospitality Management, Vol. 14 No. 3, pp. 351-374.

Bagozzi, R.P. and Yi, Y. (1988), "On the evaluation of structural equation models", Journal of the Academy of Marketing Science, Vol. 16 No. 1, pp. 74-94.

Baker, J. and Wakefield, K.L. (2012), "How consumer shopping orientation influences perceived crowding, excitement, and stress at the mall", Journal of the Academy of Marketing Science, Vol. 40 No. 6, pp. 791-806.

Banerjee, N. (2012), "A study on the attractiveness dimensions of shopping malls an Indian perspective", International Journal of Business and Social Science, Vol. 3 No. 2, pp. 102-111.

Beatley, T. (2011), Biophilic Cities: Integrating Nature into Urban Design and Planning, Island Press, Washington, DC.

Bellenger, D.N., Robertson, D.H. and Greenberg, B.A. (1977), "Shopping center patronage motives", Journal of Retailing, Vol. 53 No. 2, pp. 29-38.

Berman, B. and Evans, J.R. (1995), Retail Management: A Strategic Approach, 6th ed., Prentice-Hall Inc., Englewood Cliffs, NJ.

Biehl-Missal, B. and Saren, M. (2012), "Atmospheres of seduction: a critique of aesthetic marketing practices”, Journal of Macromarketing, Vol. 32 No. 2, pp. 168-180.

Bigne, A.J., Chumpitaz, R., Swaen, V. and Simó, L.A. (2006), "Efectos de las variables ambientales y atribución en las emociones en Centros Comerciales. Una aplicación en la compra de perfumería y cosmética", Revista española de investigación de marketing, Vol. 10 No. 17, pp. 45-68.

Bigné, E. and Andreu, L. (2004), "Emociones, satisfacción y lealtad del consumidor en entornos comerciales", Distribución y Consumo, Vol. 76 No. 2, pp. 77-87.

Boatwright, P. and Nunes, J. (2001), "Reducing assortment: an attribute-based approach", Journal of Marketing, Vol. 65 No. 3, pp. 50-63.

Bodkin, C.D. and Lord, J.D. (1997), "Attraction of power shopping centres”, The International Review of Retail, Distribution and Consumer Research, Vol. 7 No. 2, pp. 93-108.

Bollen, K.A. (1989), Structural Equations with Latent Variables, John Wiley \& Sons, New York, NY.

Brakus, J.J., Schmitt, B.H. and Zarantonello, L. (2009), "Brand experience: what is it? How is it measured? Does it affect loyalty?”, Journal of Marketing, Vol. 73 No. 3, pp. 52-68.

Brengman, M., Willems, K. and Joye, Y. (2012), "The impact of in-store greenery on customers", Psychology \& Marketing, Vol. 29 No. 11, pp. 807-821.

Browne, M.W. and Cudeck, R. (1993), "Alternative ways of assessing model fit", in Bollen, K.A. and Long, J.S. (Eds), Testing Structural Equation Models, Sage, Newbury Park, CA, pp. 136-162.

Carmines, E.G. and Zeller, R.A. (1979), Reliability and Validity Assessment, Sage Publications Series Number 07-017, Sage Publications, Inc., Newbury Park. CA.

Chebat, J.-C. and Michon, R. (2003), "Impact of ambient odors on mall shoppers' emotions, cognition, and spending", Journal of Business Research, Vol. 56 No. 7, pp. 529-539.

Chebat, J.C., Sirgy, M.J. and Grzeskowiak, S. (2010), "How can shopping mall management best capture mall image?”, Journal of Business Research, Vol. 63 No. 7, pp. 735-740.

Chin, W. (1998), “The partial least squares approach to structural equation modeling”, in Marcoulides, E.G.A. (Ed.), Modern Methods for Business Research, Lawrence Erlbaum, Mahwah, NJ, pp. 295-336.

Cohen, J. (1988), Statistical Power Analysis for the Behavioral Sciences, 2nd ed., Erlbaum, Hillsdale, NJ.

De Juan and Rivera (1999), "Los determinantes de la atracción comercial”, Investigaciones europeas de dirección y economía de la empresa, Vol. 5 No. 2, pp. 15-34.

De Juan, M.D. (2004), "Why do people choose the shopping malls? The attraction theory revisited: a Spanish case", Journal of International Consumer Marketing, Vol. 17 No. 4, pp. 71-96. 
De Nisco, A. and Rosaria Napolitano, M. (2006), "Entertainment orientation of Italian shopping centres: antecedents and performance", Managing Service Quality: An International Journal, Vol. 16 No. 2, pp. 145-166.

Dennis, C., Marsland, D. and Cockett, T. (2002), "Central place practice: shopping centre attractiveness measures, hinterland boundaries, and the UK retail hierarchy", Journal of Retailing and Consumer Services, Vol. 9 No. 4, pp. 185-199.

Dewey, J. (1922), Human Nature and Conduct, The Modern Library, New York, NY.

Attraction factors of shopping centers

Díaz, M.Á.R., Merino, A.P. and Castellanos, R.S.M. (2010), "Modelos de ecuaciones estructurales", Papeles del psicólogo, Vol. 31 No. 1, pp. 34-45.

Do Paço, A. and Raposo, M. (2009), "Green segmentation: an application to the Portuguese consumer market”, Marketing Intelligence \& Planning, Vol. 27 No. 3, pp. 364-379.

Dover, J.W. (2015), Green Infrastructure: Incorporating Plants and Enhancing Biodiversity in Buildings and Urban Environments, Routledge, New York, NY.

Driesener, C. and Romaniuk, J. (2006), "Comparing methods of brand image measurement", International Journal of Market Research, Vol. 48 No. 6, pp. 681-698.

Dwyer, F.R., Schurr, P.H. and Oh, S. (1987), "Developing buyer-seller relationships", The Journal of Marketing, Vol. 51 No. 2, pp. 11-27.

El-Adly, M.I. (2007), "Shopping malls attractiveness: a segmentation approach", International Journal of Retail \& Distribution Management, Vol. 35 No. 11, pp. 936-950.

El-Adly, M.I. and Eid, R. (2016), "An empirical study of the relationship between shopping environment, customer perceived value, satisfaction, and loyalty in the UAE malls context", Journal of Retailing and Consumer Services, Vol. 31 No. 1, pp. 217-227.

Finn, A. and Louviere, J.J. (1996), "Shopping center image, consideration, and choice: anchor store contribution", Journal of Business Research, Vol. 35 No. 3, pp. 241-251.

Fornell, C. and Larcker, D.F. (1981), "Evaluating structural equations models with unobservable variables and measurement error", Journal of Marketing Research, Vol. 18 No. 1, pp. 39-50.

Frasquet, M. (2000), Centros Comerciales: Gestión y competitividad, Generalitat Valenciana, Valencia.

Gould, E.D., Pashigian, B.P. and Prendergast, C.J. (2005), "Contracts, externalities, and incentives in shopping malls", Review of Economics and Statistics, Vol. 87 No. 3, pp. 411-422.

Hair, J.F., Ringle, C.M. and Sarstedt, M. (2011), "PLS-SEM: indeed a silver bullet”, Journal of Marketing Theory and Practice, Vol. 19 No. 2, pp. 139-152.

Hair, J.F., Ringle, C.M. and Sarstedt, M. (2012), "Editorial-partial least squares: the better approach to structural equation modeling?”, Long Range Planning, Vol. 45 Nos 5/6, pp. 312-319.

Hair, J.H., Black, W.C., Babin, B.J., Anderson, R.E. and Tatham, R.L. (2006), Multivariate Data Analysis, 6th ed., Prentice Hall, Upper Saddle River, NJ.

Haynes, J. and Talpade, S. (1996), "Does entertainment draw shoppers? The effects of entertainment centres on shopping behaviour in malls", Journal of Shopping Centre Research, Vol. 3 No. 2, pp. 29-48.

Heimstra, N.W. and McFarling, L.H. (1978), Environmental Psychology, Brooks/Cole Publishing Co., Aurora, IL.

Henseler, J., Ringle, C.M. and Sarstedt, M. (2015), "A new criterion for assessing discriminant validity in variance-based structural equation modeling", Journal of the Academy of Marketing Science, Vol. 43 No. 1, pp. 115-135.

Henseler, J., Ringle, C.M. and Sinkovics, R.R. (2009), "The use of partial least squares path modeling in international marketing", Advances in International Marketing, Vol. 20 No. 1, pp. 277-319.

Herzog, T.R. and Strevey, S.J. (2008), "Contact with nature, sense of humor, and psychological well-being”, Environment \& Behavior, Vol. 40 No. 6, pp. 747-776. 
EJMBE 26,2

Hira, F. and Mehvish, R. (2012), "Determining the factors affecting consumer loyalty towards shopping malls", Global Advanced Research Journal of Management and Business Studies, Vol. 1 No. 4, pp. 134-140.

Hoffman, K.D. and Turley, L.W. (2002), "Atmospherics, service encounters and consumer decision making: an integrative perspective", Journal of Marketing Theory and Practice, Vol. 10 No. 3, pp. 33-47.

Hollander, S.C. (1960), “The wheel of retailing”, The Journal of Marketing, Vol. 25 No. 1, pp. 37-42.

Howard, E. (1992), "Evaluating the success of out of-town regional shopping centers", The International Review of Retail, Distribution and Consumer Research, Vol. 2 No. 1, pp. 59-80.

Howard, E. (1997), “The management of shopping centres: conflict or collaboration?”, The International Review of Retail, Distribution and Consumer Research, Vol. 7 No. 3, pp. 263-285.

Hu, L.T. and Bentler, P.M. (1998), "Fit indices in covariance structure modeling: sensitivity to underparameterized model misspecification”, Psychological Methods, Vol. 3 No. 4, pp. 424-453.

Iturriagagoitia, M.A. and de Madariaga, J.G. (2010), "Diversión en el Centro Comercial”, Distribución y Consumo, Vol. 20 No. 111, pp. 78-89.

Jha, S. and Singh, B. (2014), "Consumer behaviour and moderating effect of frequency of visit in relation to atmospheric cues: an experimental study", Indian Journal of Marketing, Vol. 44 No. 2, pp. 53-59.

Jiménez, S.M., Guillén, M.J.Y. and García, C. (2015), "El marketing sensorial: una aproximación al mundo del retail español”, Distribución y Consumo, Vol. 25 No. 138, pp. 88-95.

Jöreskog, K.G. and Sörbom, D. (1996), LISREL 8: User's Reference Guide, Scientific Software International, Lincolnwood, IL.

Joye, Y., Willems, K., Brengman, M. and Wolf, K. (2010), "The effects of urban retail greenery on consumer experience: reviewing the evidence from a restorative perspective", Urban Forestry \& Urban Greening, Vol. 9 No. 1, pp. 57-64.

Kaiser, H.F. (1974), “An index of factorial simplicity”, Psychometrika, Vol. 39 No. 1, pp. 31-36.

Kaplan, R. and Kaplan, S. (1989), The Experience of Nature: A Psychological Perspective, Cambridge University Press, New York, NY.

Kaplan, S. (1995), "The restorative benefits of nature: toward an integrative framework", Journal of Environmental Psychology, Vol. 15 No. 3, pp. 169-182.

Kerlinger, F. and Lee, H. (2002), Investigación del comportamiento. Métodos de investigación en las ciencias sociales, McGraw-Hill, México City.

Khei, M.W.G., Lu, Y. and Lan, Y.L. (2001), "SCATTR: an instrument for measuring shopping centre attractiveness", International Journal of Retail \& Distribution Management, Vol. 29 No. 2, pp. 76-86.

Kim, J.W., Lee, F. and Suh, Y.G. (2015), "Satisfaction and loyalty from shopping mall experience and brand personality", Services Marketing Quarterly, Vol. 36 No. 1, pp. $62-76$.

Kim, Y. and Han, H. (2010), "Intention to pay conventional-hotel prices at a green hotel - a modification of the theory of planned behavior", Journal of Sustainable Tourism, Vol. 18 No. 8, pp. 997-1014.

Kim, Y.K. (2001), "Experiential retailing: an interdisciplinary approach to success in domestic and international retailing", Journal of Retailing and Consumer Services, Vol. 8 No. 5, pp. 287-289.

Kim, Y.K. (2002), “Consumer value: an application to mall and internet shopping”, International Journal of Retail \& Distribution Management, Vol. 30 No. 12, pp. 595-602.

Kline, R.B. (2005), Principies and Practice of Structural Equation Modeiing, 2nd ed., Guilford, New York, NY.

Kotler, P. (1973), “Atmospherics as a marketing tool”, Journal of Retailing, Vol. 49 No. 4, pp. 48-64.

Lee, J.S., Hsu, L.T., Han, H. and Kim, Y. (2010), "Understanding how consumers view green hotels: how a hotel's green image can influence behavioural intentions", Journal of Sustainable Tourism, Vol. 18 No. 7, pp. 901-914.

McGoldrick, P.J. and Thompson, M.G. (1992), Regional Shopping Centres, Avebury, London. 
Más Ruiz, F.J. (1999), "Image of suburban shopping malls and two-stage versus uni-equational modelling of the retail trade attraction: an empirical application", European Journal of Marketing, Vol. 33 Nos 5/6, pp. 512-531.

Mehrabian, A. and Russell, J.A. (1974), An Approach to Environmental Psychology, MIT Press, Cambridge, MA.

Michon, R., Chebat, J.C. and Turley, L.W. (2005), "Mall atmospherics: the interaction effects of the mall environment on shopping behavior", Journal of Business Research, Vol. 58 No. 5, pp. 576-583.

Attraction factors of shopping centers

Michon, R., Chebat, J.C., Yu, H. and Lemarié, L. (2015), "Fashion orientation, shopping mall environment, and patronage intentions: a study of female fashion shoppers", Journal of Fashion Marketing and Management, Vol. 19 No. 1, pp. 3-21.

Micu, C.B. (2013), "The concept of shopping centre attractiveness - literature review", Proceedings of the International Conference Marketing-from Information to Decision, Vol. 6, pp. 145-157.

Mishra, H.G., Sinha, P.K. and Koul, S. (2014), "Impact of store atmospherics on customer behavior: influence of response moderators", Journal of Business and Management, Vol. 20 No. 1, pp. 45-66.

Munuera, J.L. and Cuestas, P.J. (2006), "Factores de atracción de los Centros Comerciales en España", Información Comercial Española: Revista de economía, Enero-Febrero No. 828, pp. 99-116.

Netemeyer, R.G., Bearden, W.O. and Sharma, S. (2003), Scaling Procedures: Issues and Applications, Sage Publications, Thousand Oaks, CA.

North, E.J. and Kotze, T. (2004), "Customer perceptions of the attractiveness of shopping centres in Pretoria", Southern African Business Review, Vol. 8 No. 1, pp. 30-38.

Nunnally, J.C. and Bernstein, I.H. (1994), Psychometric Theory, 3rd ed., McGraw Hill, New York, NY.

Ortegon, L. and Gomez, A. (2017), "Gestión del marketing sensorial sobre la experiencia del consumidor", Revista de Ciencias Sociales, Vol. 22 No. 3, pp. 67-83.

Ortegon, L. and Royo, M. (2015), "Brand image and lexicographic analysis: an application to shopping malls", Cuadernos de Gestión, Vol. 15 No. 2, pp. 143-162.

Park, S. (2016), "What attracts you to shopping malls?: the relationship between perceived shopping value and shopping orientation on purchase intention at shopping malls in suburban areas", Celebrating America's Pastimes: Baseball, Hot Dogs, Apple Pie and Marketing, Springer International Publishing, Denver, CO, pp. 663-669.

Porral, C.C. and Dopico, D.C. (2013), "Estudio exploratorio sobre los factores de atracción de Centros Comerciales: una aproximación al consumidor español", CIENCIA ergo-sum, Vol. 20 No. 2, pp. 107-120.

Rajagopal, P. (2009), "Growing shopping malls and behaviour of urban shoppers", Journal of Retail \& Leisure Property, Vol. 8 No. 2, pp. 99-118.

Robert, D. and John, R. (1982), "Store atmosphere: an environmental psychology approach”, Journal of Retailing, Vol. 58 No. 1, pp. 34-57.

Rogerson, J.M. and Sims, S.R. (2012), "The greening of urban hotels in South Africa: evidence from Gauteng”, Urban Forum, Vol. 23 No. 3, pp. 391-407.

Ruíz, F.J. (1999), "Image of suburban shopping malls and two-stage vs uni-equational modelling of the retail trade attraction: an empirical application”, European Journal of Marketing, Vol. 33 Nos 5/6, pp. 512-531.

Schumacker, R.E. and Lomax, R.G. (2004), A Beginner's Guide to Structural Equation Modeling, Lawrence Erlbaum Associates, Publishers, Mahwah, NJ and London.

Sierra, B., Alier, E. and Falces, C. (2000), "Los efectos de las variables ambientales sobre la conducta del consumidor”, Distribución y Consumo, Vol. 54, Octubre-Noviembre, pp. 5-21.

Singh, H. and Prashar, S. (2013), "Factors defining shopping experience: an analytical study of Dubai", Asian Journal of Business Research, Vol. 3 No. 1, pp. 36-51.

Sit, J., Merrilees, B. and Birch, D. (2003), "Entertainment-seeking shopping centre patrons: the missing segments", International Journal of Retail \& Distribution Management, Vol. 31 No. 2, pp. 80-94. 
EJMBE 26,2

Sit, J.K. and Birch, D. (2014), "Entertainment events in shopping malls profiling passive and active participation behaviors", Journal of Consumer Behaviour, Vol. 13 No. 6, pp. 383-392.

Söderlund, J. and Newman, P. (2015), "Biophilic architecture: a review of the rationale and outcomes", AIMS Environmental Science, Vol. 2 No. 4, pp. 950-969.

Spence, C., Puccinelli, N.M., Grewal, D. and Roggeveen, A.L. (2014), "Store atmospherics: a multisensory perspective", Psychology \& Marketing, Vol. 31 No. 7, pp. 472-488.

Srinivasan, S.R. and Srivastava, R.K. (2010), "Creating the futuristic retail experience through experiential marketing: is it possible? An exploratory study", Journal of Retail \& Leisure Property, Vol. 9 No. 3, pp. 193-199.

Steiger, J.H. (1990), "Structural model evaluation and modification: an interval estimation approach", Multivariate Behavioral Research, Vol. 25 No. 2, pp. 173-180.

Suárez, L.M.C. (2016), "Dimensiones clave para revitalizar áreas comerciales urbanas: El caso de Getafe, España”, Revista de Ciencias Sociales, Vol. 22 No. 1, pp. 98-109.

Suárez, L.M.C., Nogales, A.F. and Arévalo, A.R. (2007), "Atributos para el éxito de una zona comercial: una evidencia empírica en el municipio de Getafe", Distribución y Consumo, Vol. 95, Septiembre-Octubre, pp. 16-31.

Suárez, M.G. and Gumiel, C.G. (2012), "Marketing sensorial”, Distribución y Consumo, Vol. 22 No. 122, pp. 30-39.

Sujo, T. and Bharati, P. (2012), "A study of consumer behavior approach towards shopping mall attractiveness with special reference to the city of Ahmedabad", Research Journal of Social Science and Management, Vol. 2 No. 5, pp. 146-154.

Tandon, A., Gupta, A. and Tripathi, V. (2016), "Managing shopping experience through mall attractiveness dimensions: an experience of Indian metro cities", Asia Pacific Journal of Marketing and Logistics, Vol. 28 No. 4, pp. 634-649.

Teller, C. and Reutterer, T. (2008), "The evolving concept of retail attractiveness: what makes retail agglomerations attractive when customers shop at them?", Journal of Retailing and Consumer Services, Vol. 15 No. 3, pp. 127-143.

Turley, L.W. and Milliman, R.E. (2000), "Atmospheric effects on shopping behavior: a review of the experimental evidence", Journal of Business Research, Vol. 49 No. 2, pp. 193-211.

Valdivieso, T.C. (2013), "Comparación de los modelos formativo, reflexivo y de antecedentes de evaluación estudiantil del servicio de docencia”, Revista de Métodos Cuantitativos para la Economía y la Empresa, Vol. 16 No. 1, pp. 95-120.

Vigaray, J.M. and Camino, R.J. (1999), "Los determinantes de la atracción comercial", Investigaciones Europeas de dirección y economía de la empresa, Vol. 5 No. 2, pp. 15-34.

Wakefield, K.L. and Baker, J. (1998), "Excitement at the mall: determinants and effects on shopping response", Journal of Retailing, Vol. 74 No. 4, pp. 515-539.

Weinmaster, M. (2009), “Are green walls as 'green' as they look? An introduction to the various technologies and ecological benefits of green walls", Journal of Green Building, Vol. 4 No. 4, pp. 3-18.

Werts, C.E., Linn, R.L. and Joreskog, K.G. (1974), "Intraclass reliability estimates: testing structural assumptions", Educational and Psychological Measurement, Vol. 34 No. 1, pp. 25-34.

Wolf, K.L. (2005), "Trees in the small city retail business district: comparing resident and visitor perceptions", Journal of Forestry, Vol. 103 No. 8, pp. 390-395.

\section{Further reading}

Cepeda, G. and Roldán, J.L. (2004), "Aplicando en la práctica la técnica PLS en la administración de empresas”, XIV Congreso de ACEDE, Madrid, Septiembre de.

Chin, W. and Newsted, P.R. (1999), "Structural equation modeling analysis with small samples using partial least squares", in En Hoyle, R.H. (Ed.), Statistical Strategies for Small Sample Research, Sage Publications, Thousand Oaks, CA, pp. 352-380. 
Cupani, M. (2012), "Análisis de Ecuaciones Estructurales: Conceptos, etapas de desarrollo y un ejemplo de aplicación”, Revista Tesis, Vol. 2 No. 1, pp. 186-199.

Faul, F., Erdfelder, E., Lang, A.-G. and Buchner, A. (2007), "G*Power 3: a flexible statistical power analysis program for the social, behavioral, and biomedical sciences", Behavior Research Methods, Vol. 39 No. 2, pp. 175-191.

Attraction factors of shopping centers

Hair, J.H., Anderson, R.E., Tatham, R.L. and Black, W.C. (1995), Multivariate Data Analysis, 4th ed., Prentice Hall, Englewood Cliffs, NJ.

Hu, H. and Jasper, C. (2015), "Consumer shopping experience in the mall: conceptualization and measurement", Proceedings of the 2007 Academy of Marketing Science (AMS) Annual Conference, Springer International Publishing, Denver, CO, p. 8.

Ringle, C.M., Wende, S. and Becker, J.M. (2015), "SmartPLS 3", Recuperado en, available at: www. smartpls.com (accessed November 2015).

\section{Corresponding author}

Marcelo Royo-Vela can be contacted at: Marcelo.Royo@uv.es

For instructions on how to order reprints of this article, please visit our website: 